Prepared in cooperation with the Truckee Meadows Water Authority

\title{
Traveltime Data for the Truckee River Between Tahoe City, California, and Vista, Nevada, 2006 and 2007
}

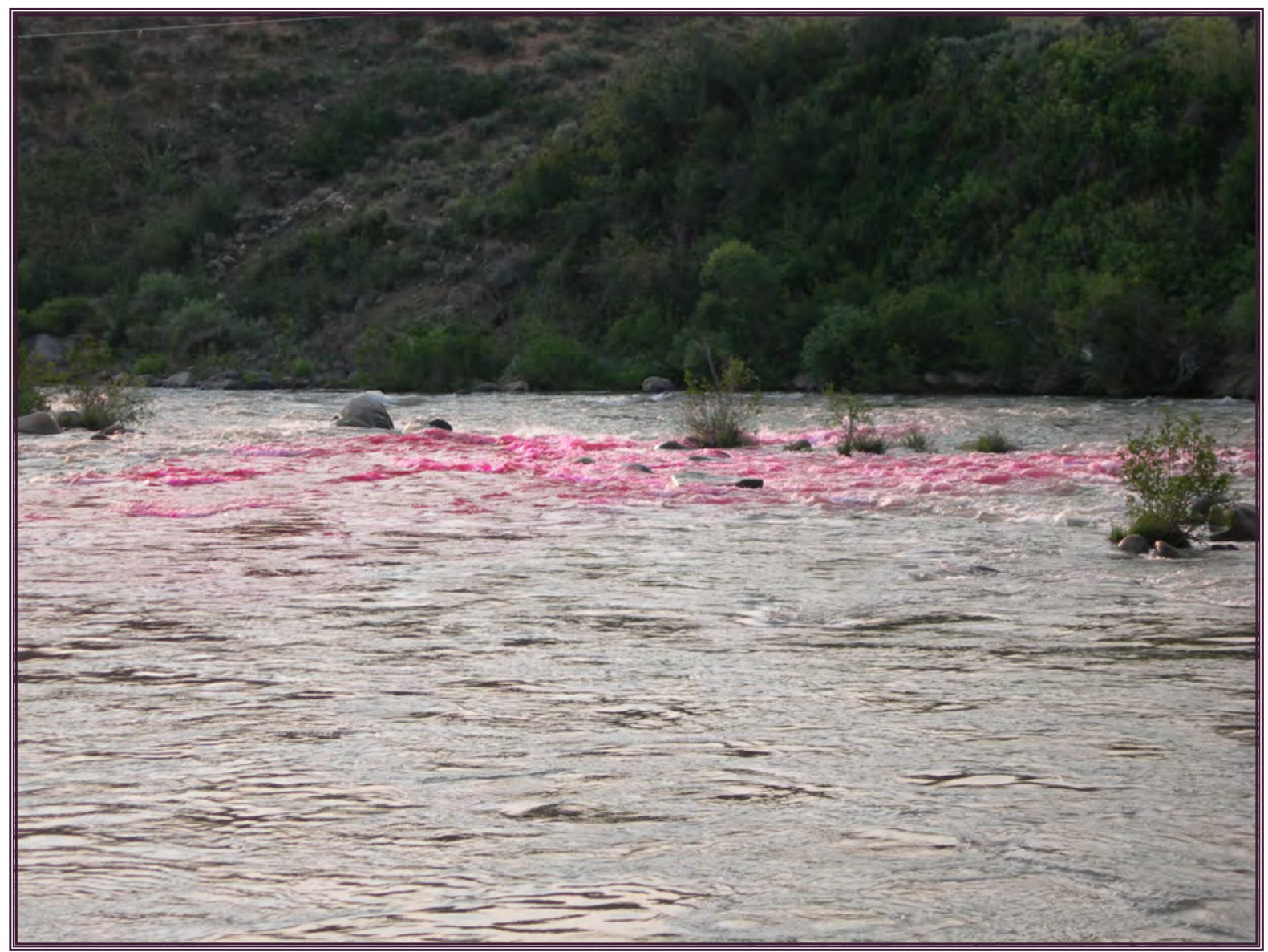

Open-File Report 2008-1084 


\section{Traveltime Data for the Truckee River Between Tahoe City, California, and Vista, Nevada, 2006 and 2007}

By E. James Crompton

Prepared in cooperation with the Truckee Meadows Water Authority

Open-File Report 2008-1084 


\section{U.S. Department of the Interior DIRK KEMPTHORNE, Secretary}

\section{U.S. Geological Survey \\ Mark D. Myers, Director}

U.S. Geological Survey, Reston, Virginia: 2008

For product and ordering information:

World Wide Web: http://www.usgs.gov/pubprod

Telephone: 1-888-ASK-USGS

For more information on the USGS--the Federal source for science about the Earth, its natural and living resources, natural hazards, and the environment:

World Wide Web: http://www.usgs.gov

Telephone: 1-888-ASK-USGS

Any use of trade, product, or firm names is for descriptive purposes only and does not imply endorsement by the U.S. Government.

Although this report is in the public domain, permission must be secured from the individual copyright owners to reproduce any copyrighted materials contained within this report.

Suggested citation:

Crompton, E.J., 2008, Traveltime data for the Truckee River between Tahoe City, California, and Vista, Nevada, 2006 and 2007: U.S. Geological Survey Open-File Report 2008-1084, 12 p. 


\section{Contents}

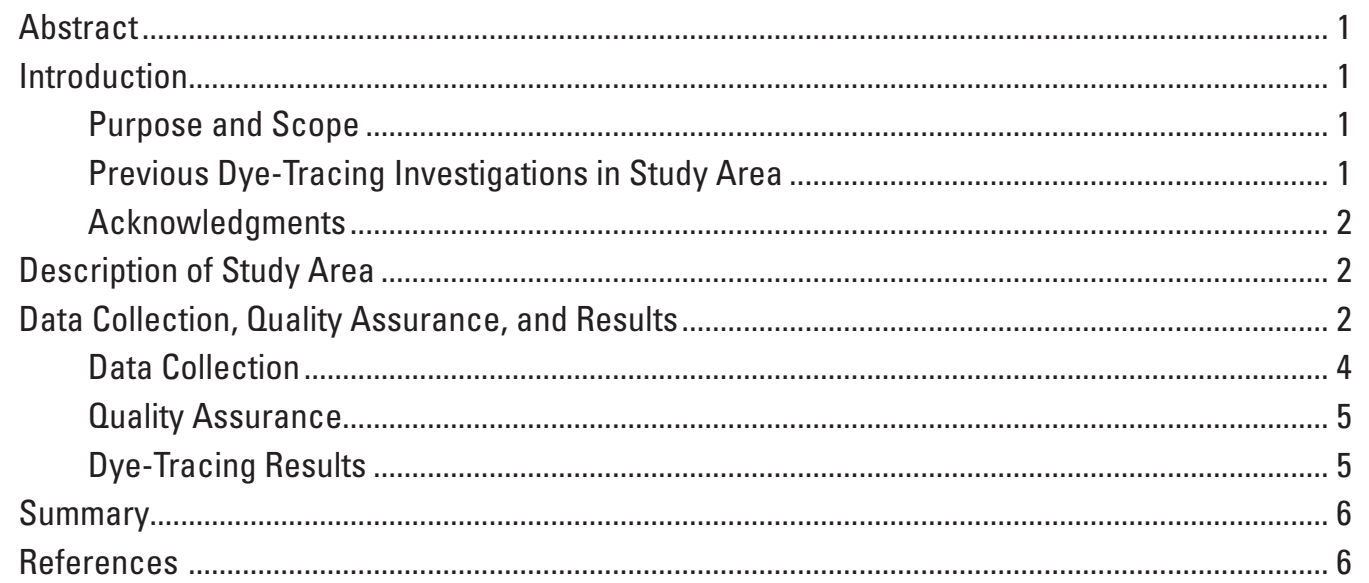

\section{Figures}

1. Map showing general location of Truckee River injection or sampling sites used in traveltime studies

2-4. Graphs showing observed response curves for the Truckee River reach between:

2. Tahoe City, Calif., and Boca Bridge near Truckee, Calif., May 22-24, 2007........................ 10

3. Glenshire Drive near Truckee, Calif. and Mogul, Nev., June 29, 2006............................. 11

4. Mogul, Nev., and Vista, Nev., June 27, 2006. .............................................................. 12

\section{Tables}

1. Truckee River traveltime study injection and sampling sites ........................................................ 4

2-4. Rhodamine WT dye concentration data from traveltime study on the Truckee River between:

2. Tahoe City, Calif., and Boca Bridge near Truckee, Calif., May 22-24, 2007 .......................... 7

3. Glenshire Drive near Truckee, Calif., and Mogul, Nev., June 29, 2006.............................. 8

4. Mogul, Nev., and Vista, Nev., June 27, 2006. ................................................................. 9 


\section{Conversion Factors and Vertical Datum}

\begin{tabular}{lll}
\hline \multicolumn{1}{c}{ Multiply } & \multicolumn{1}{c}{ By } & \multicolumn{1}{c}{ To obtain } \\
\hline foot $(\mathrm{ft})$ & 0.3048 & meter $(\mathrm{m})$ \\
foot per mile $(\mathrm{ft} / \mathrm{mi})$ & 0.1894 & meter per kilometer $(\mathrm{m} / \mathrm{km})$ \\
mile $(\mathrm{mi})$ & 1.609 & kilometer $(\mathrm{km})$ \\
square mile $\left(\mathrm{mi}^{2}\right)$ & 2.590 & square kilometer $\left(\mathrm{km}^{2}\right)$ \\
cubic foot $\left(\mathrm{ft}^{3}\right)$ & 0.02832 & cubic meter $\left(\mathrm{m}^{3}\right)$ \\
cubic foot per second $\left(\mathrm{ft}^{3} / \mathrm{s}\right)$ & 0.02832 & cubic meter per second $\left(\mathrm{m}^{3} / \mathrm{s}\right)$ \\
\hline
\end{tabular}

Abbreviated water-quality units used in this report:

$\mu \mathrm{g} / \mathrm{L} \quad$ microgram per liter

Datums

Vertical coordinate information is referenced to the National Geodetic Vertical Datum of 1929 (NGVD of 1929, formerly called "Sea-level Datum of 1929")

Altitude, as used in this report, refers to distance above the vertical datum. 


\title{
Traveltime Data for the Truckee River between Tahoe City, California, and Vista, Nevada, 2006 and 2007
}

\author{
By E. James Crompton
}

\begin{abstract}
Traveltime measurements were made during 2006 and 2007 along the Truckee River between Tahoe City, Calif., and Vista, Nev. Fluorescent rhodamine WT dye was injected at various locations along the river during streamflows ranging from 143 to 2,660 cubic feet per second.

The resulting data, presented in tabular and graphic form, may be useful to water-quality modelers or water-resources managers concerned with predicting the movement of soluble contaminants accidentally spilled into the Truckee River. The data provided in this report also could be used to determine the dispersion-related characteristics (duration and magnitude of pollutant concentrations) that may be expected in the Truckee River.
\end{abstract}

\section{Introduction}

The use of dyes and tracing techniques provides a means of measuring the traveltime and dispersion characteristics of streams. Traveltime may be defined as the time it takes for water or soluble constituents introduced into a river to move downstream from one point to another. Introduced constituents tend to disperse as they move downstream causing peak concentrations to decrease and the length of the solute plume to increase. Dye tracing involves the instantaneous injection of a nontoxic, fluorescent dye at a location along the stream and sampling of the resulting dye plume at locations downstream (Buchanan, 1964; Wilson, 1968). The dye mixes with the water and moves in the same manner as the water.

Information on traveltime of solutes may be required for water-quality modeling or waste-transport studies and also provides an objective means for determining an appropriate course of action in response to the spilling of a soluble toxic substance. The simulation model results are usually no better quantitatively than the traveltime data used in their development because simulation of biochemical processes in water-quality models involves the calculation of timedependent reactions. Although mean streamflow velocity may be computed from streamflow measurements made at gaging stations, such point data may not adequately characterize an entire stream reach. Extrapolation of such point data may be subject to large errors. Officials responsible for public safety (including water-supply managers and regulators) and others interested in transient water-quality problems need to be able to predict passage and arrival times or peak concentration of a noxious substance released or spilled upstream. Accurate traveltime information is needed to provide a reasonable basis for deciding whether, when, and how long to suspend operations of public water-supply intakes or how best to handle any perceived threat to the river environment.

\section{Purpose and Scope}

This report describes the techniques and presents the results (in tabular and graphical form) of three dye injections in 2006 and 2007 during two flow conditions on the Truckee River between Tahoe City, Calif., and Vista, Nev. Two of the three events were during high-flow conditions (greater than $1,000 \mathrm{ft}^{3} / \mathrm{s}$ ), and one was during medium-flow conditions $\left(143-637 \mathrm{ft}^{3} / \mathrm{s}\right)$. The high-flow injections were in June 2006 and the medium-flow injection was in May 2007.

\section{Previous Dye-Tracing Investigations in Study Area}

La Camera and others (1985) published, in tabular form, the physical, chemical, and biological data collected as part of the Truckee and Carson River Basins river-quality assessment (Nowlin and others, 1980) in support of water-quality modeling and investigations of trout-spawning habitats in the Truckee River system. La Camera and others (1985) included the results from 13 dye-tracer events during 1979-80 for a wide range of flows in three reaches along the Truckee River. The three reaches were from Truckee, Calif., to Vista, Nev.; from Vista to Derby Diversion Dam (hereafter, "Derby Dam") near Wadsworth, Nev.; and from Derby Dam to Marble Bluff Dam near Nixon, Nev.

Brown and others (1986) analyzed the data published by La Camera and others (1985) and provided an overview of the Truckee River hydrologic system; presented data and computed relations in graphical, tabular, and map form; and interpreted the raw and computed data. The computed relations were used in equations to relate velocities to flows in 43 reaches of the Truckee River from Sparks to Pyramid Lake 
Traveltime Data for the Truckee River Between Tahoe City, California, and Vista, Nevada, 2006 and 2007

for water-quality modeling (Nowlin, 1987). The velocity-flow relations developed by Nowlin (1987) also were used in more recent water-quality models of the Truckee River (Caupp and others, 1997).

Bohman (2000) did four traveltime events during lowflow conditions (12-161 $\left.\mathrm{ft}^{3} / \mathrm{s}\right)$ on the Truckee River during November and December 1993. The four river reaches studied by Bohman (2000) were from the confluence of Steamboat Creek and the Truckee River near Sparks, Nev., to Derby Dam near Wadsworth, Nev.; from Derby Dam near Wadsworth, Nev., to Wadsworth, Nev.; from Wadsworth, Nev., to Dead Ox Wash near Nixon, Nev.; and from Dead Ox Wash near Nixon, Nev., to Marble Bluff Dam near Nixon, Nev. The 1993 data were tabulated and combined with the 1979-80 data published in La Camera and others (1985) and graphical relations between traveltime and distance and between traveltime and flow are presented.

Crompton and Bohman (2000) performed eight traveltime events on the Truckee River during 1999. Three river reaches were studied during both high-flow $\left(2,130-2,780 \mathrm{ft}^{3} / \mathrm{s}\right)$ and medium-flow (330-570 $\left.\mathrm{ft}^{3} / \mathrm{s}\right)$ conditions and were from Mogul, Nev., to Vista, Nev.; Vista, Nev., to Wadsworth, Nev.; and Wadsworth, Nev., to Marble Bluff Dam near Nixon, Nev. The two additional river reaches, from Tahoe City, Nev., to Boca Bridge near Truckee, Calif., and Old US Highway 40 Bridge near Truckee, Calif. (Glenshire Drive near Truckee, Calif.), to Mogul, Nev., were studied during medium-flow (173-627 ft $3 / \mathrm{s}$ ) conditions. The results were presented in tabular and graphical form.

\section{Acknowledgments}

The author wishes to acknowledge the assistance of personnel from Truckee Meadows Water Authority and the Hydrologic Sciences Program in the College of Agriculture, Biotechnology, and Natural Resources at the University of Nevada, Reno, in the collection of the field data.

\section{Description of Study Area}

The physical and hydrologic characteristics of the Truckee River are described in detail by Van Denburgh and others (1973), Brown and others (1986), and Jones and others (1991). A general location map of the study area, including the dye injection and sampling sites, is shown in figure 1.

The Truckee River watershed is a closed basin on the eastern slope of the Sierra Nevada along the CaliforniaNevada border. In the part of the basin that surrounds Lake Tahoe, altitudes exceed 10,000 ft above sea level. The lowest part of the basin is at the river's terminus, Pyramid Lake, where the altitude of the lake surface is approximately 3,800 $\mathrm{ft}$ above sea level. The study area is the reach of the Truckee River from Tahoe City, Calif. (site 1, fig. 1) to Vista, Nev. (site 12). The drainage area of the study area is $1,430 \mathrm{mi}^{2}$ for the 63-mi-long stretch of the Truckee River above Vista (which is $53.38 \mathrm{mi}$ above Marble Bluff Dam and about $56 \mathrm{mi}$ upstream from the mouth at Pyramid Lake).

From the outlet of Lake Tahoe, the Truckee River flows generally north about $15 \mathrm{mi}$ to Truckee, Calif., then northeasterly for about $28 \mathrm{mi}$ across the State line to Verdi, Nev. Downstream from Verdi, the river flows to the east about 20 mi to Vista, Nev. Several major tributaries, all of which are controlled by reservoirs, join the Truckee River downstream from Tahoe City; they include Donner Creek, Martis Creek, Prosser Creek and the Little Truckee River. Just downstream from the mouth of the Little Truckee River, the Truckee River flows through a deeply incised canyon to the CaliforniaNevada border. About $8 \mathrm{mi}$ east of the border, the river passes through an alluvial valley bounded by mountain ranges. This area, known as the Truckee Meadows, includes the cities of Reno and Sparks. Although the current economy of the area is dominated by commercial and industrial businesses, Truckee Meadows still contains irrigated agricultural lands. Both municipal and agricultural water needs are satisfied by diversions at 10 locations along the river within and upstream from the Truckee Meadows. Two hydroelectric plants are located in the western part of the Truckee Meadows; both these plants are run-of-river and divert part of the streamflow from the Truckee River near Verdi, Nev. Irrigation return flows from diversions originating on the north side of the river between Verdi and Reno and some natural flow enters the Truckee River via the North Truckee Drain near Vista, just east of Sparks, Nev. Irrigation return flows from diversions originating on the south side of the river between Verdi and Sparks, Nev., treated municipal-sewage effluent, and additional natural flows enter the river from Steamboat Creek, also near Sparks. The Truckee Meadows Water Reclamation Facility (formerly called the Reno-Sparks sewage-treatment plant) is near the mouth of Steamboat Creek.

River gradients vary between the lower basin and the steeper mountain-block area of the upper basin. The gradient of the river is fairly steep above Reno, Nev., averaging about $35 \mathrm{ft} / \mathrm{mi}$. Within the 8-mi reach of the river from Reno downstream to Vista, the gradient is relatively flat (about 1.6 $\mathrm{ft} / \mathrm{mi})$. The numerous diversion structures have important localized effects on the channel slope. Resultant decreases in flow velocities and increases in flow depths upstream from diversion structures undoubtedly influence both traveltime and dispersion characteristics of the river (Nowlin, 1987).

\section{Data Collection, Quality Assurance, And Results}

This report presents the results of three dye injections. Two injections were under high-flow conditions during June 2006, and one injection was under medium-flow conditions during May 2007. Locations of the dye injection sites are shown in figure 1and listed in table 1. 


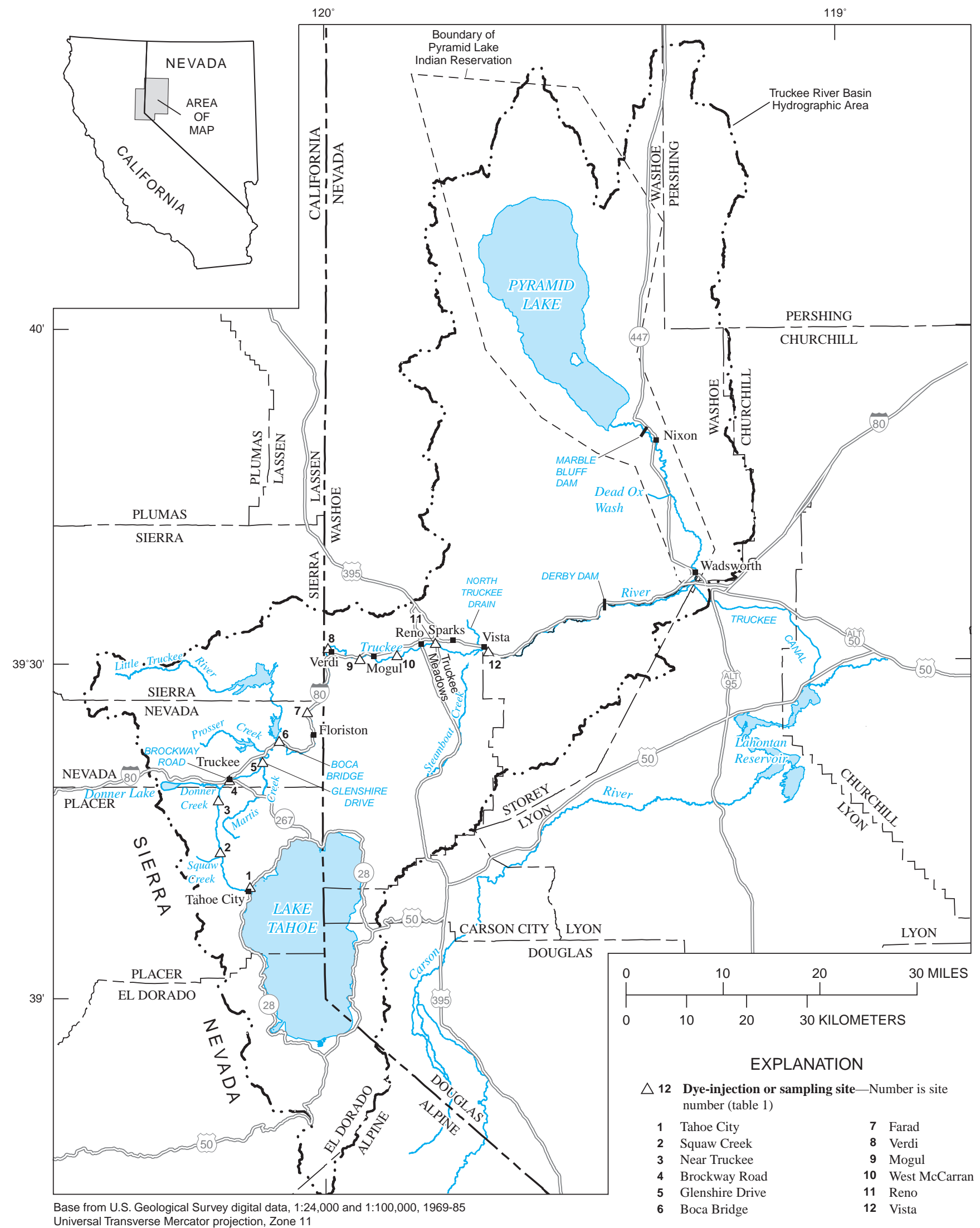

Figure 1. General location of Truckee River injection or sampling sites used in traveltime studies. See table 1 for full site names. 


\section{Data Collection}

Field procedures for traveltime and dispersion studies on streams using dye tracers are well documented (Kilpatrick and Wilson, 1989). In general, those procedures were followed closely during the 2006 and 2007 Truckee River dye injections.

The two Truckee River reaches studied in 2006 were from Glenshire Drive near Truckee, Calif. (site 5, fig. 1 and table 1), to near Mogul, Nev. (site 9); and from near Mogul, Nev., to Vista, Nev. (site 12). One Truckee River reach, studied in 2007, was from Tahoe City, Calif. (site 1) to Boca Bridge near Truckee, Calif. (site 6). For each study reach, a minimum of three sampling sites downstream from the injection point were selected. Accessibility and suitability for making streamflow measurements over a range of flows were considered in site selection. Sampling sites were far enough downstream from the injection sites that complete lateral mixing could be assumed. Tributary inflows, analogous to a side injection of clear water, cause lateral-mixing problems at nearby downstream sampling sites. Dye-measurement sites were chosen to be sufficiently downstream from tributary inflows for the water and dye to be fully mixed. Despite these precautions, Squaw Creek and Little Truckee River inflows may have caused poor mixing at the sites below Squaw Creek near Tahoe City, Calif. (site 2) and Boca Bridge near Truckee, Calif. (site 6), respectively, during the medium-flow dye injection.

Single-slug (instantaneous) dye injections were made near the center of active flow. Rhodamine WT dye was used in the studies because it is less susceptible than other dye types to loss by contact with aquatic plants, suspended clays, and the streambed and streambanks. The Rhodamine WT liquid concentrate dye was used for this study has 20 percent dye content, color strength of 2.33 milligrams per 100 milliliters, and a specific gravity of 1.25 . For each injection, the type and amount of dye, time and location of injection, and the measured streamflow were recorded. The amount of dye to be injected at the upstream end of each study reach was determined by using general empirical relations (Kilpatrick and Wilson, 1989) that are dependent upon the maximum streamflow anticipated for the reach, velocity, reach length, and dye concentration. These dye amounts typically were chosen so peak concentrations at the downstream end of each study reach or at municipal water intakes did not exceed $10 \mu \mathrm{g} / \mathrm{L}$.

Fluorometers were used in the field and in the laboratory to determine the presence and concentration of dye in the samples collected. Fluorometers measure the fluorescence of

Table 1. Truckee River traveltime study injection and sampling sites.

[River miles are based on Brown and others (1986). Abbreviations: ft, feet; mi, mile; —, not applicable; I, injection; S, sampling]

\begin{tabular}{|c|c|c|c|c|c|c|}
\hline $\begin{array}{l}\text { Site } \\
\text { No. }\end{array}$ & $\begin{array}{l}\text { USGS } \\
\text { Station } \\
\text { Number }\end{array}$ & Station Name & $\begin{array}{l}\text { River miles } \\
\text { above } \\
\text { Marble } \\
\text { Bluff Dam }\end{array}$ & $\begin{array}{l}\text { Latitude } \\
\text { Longitude }\end{array}$ & $\begin{array}{l}\text { Site } \\
\text { Type }\end{array}$ & Remarks \\
\hline 2 & & $\begin{array}{l}\text { Truckee River below Squaw Creek } \\
\text { near Tahoe City, Calif. }\end{array}$ & 110.10 & $\begin{array}{l}39^{\circ} 12^{\prime} 42^{\prime \prime} \mathrm{N} . \\
120^{\circ} 11^{\prime} 54^{\prime \prime} \mathrm{W}\end{array}$ & $S$ & $\begin{array}{l}\text { Sampled near center of channel under private } \\
\text { bridge below Squaw Creek. }\end{array}$ \\
\hline 3 & 10338000 & Truckee River near Truckee, Calif. & 103.62 & $\begin{array}{l}39^{\circ} 19^{\prime} 14^{\prime \prime} \mathrm{N} . \\
120^{\circ} 17^{\prime} 47^{\prime \prime} \mathrm{W}\end{array}$ & S & Sampled near center of channel at gaging station. \\
\hline 4 & 10339010 & $\begin{array}{l}\text { Truckee River at Brockway Road at } \\
\text { Truckee, Calif. }\end{array}$ & 100.86 & $\begin{array}{l}39^{\circ} 19^{\prime} 36^{\prime \prime} \mathrm{N} . \\
120^{\circ} 11^{\prime} 00^{\prime \prime} \mathrm{W} .\end{array}$ & $\mathrm{S}$ & Sampled near right bank under bridge. \\
\hline 5 & & $\begin{array}{l}\text { Truckee River at Glenshire Drive } \\
\text { near Truckee, Calif. }\end{array}$ & 96.14 & $\begin{array}{l}39^{\circ} 21^{\prime} 11^{\prime \prime} \mathrm{N} . \\
120^{\circ} 07^{\prime} 17^{\prime \prime} \mathrm{W} .\end{array}$ & $\mathrm{I} / \mathrm{S}$ & $\begin{array}{l}\text { Dye injected at downstream side of Glenshire } \\
\text { Road bridge; samples collected from center of } \\
\text { channel under bridge. }\end{array}$ \\
\hline 8 & 10347320 & $\begin{array}{l}\text { Truckee River at Bridge Street at } \\
\text { Verdi, Nev. }\end{array}$ & 73.50 & $\begin{array}{l}39^{\circ} 31^{\prime} 27^{\prime \prime} \mathrm{N} . \\
119^{\circ} 59^{\prime} 32^{\prime \prime} \mathrm{W}\end{array}$ & $S$ & Sampled downstream of bridge near right bank. \\
\hline 9 & 10347460 & Truckee River near Mogul, Nev. & 68.74 & $\begin{array}{l}39^{\circ} 30^{\prime} 26^{\prime \prime} \mathrm{N} . \\
119^{\circ} 55^{\prime} 51^{\prime \prime} \mathrm{W}\end{array}$ & $\mathrm{I} / \mathrm{S}$ & $\begin{array}{l}\text { Dye injected from downstream side of bridge at } \\
\text { gaging station; samples collected near right } \\
\text { bank across from gaging station. }\end{array}$ \\
\hline 10 & & $\begin{array}{l}\text { Truckee River above West McCarran } \\
\text { Boulevard at Reno, Nev. }\end{array}$ & 63.97 & $\begin{array}{l}39^{\circ} 30^{\prime} 40^{\prime \prime} \mathrm{N} . \\
119^{\circ} 51^{\prime} 41^{\prime \prime} \mathrm{W} .\end{array}$ & $\mathrm{S}$ & $\begin{array}{l}\text { Sampled near right bank about } 570 \mathrm{ft}(0.11 \mathrm{mi}) \\
\text { upstream from bridge. }\end{array}$ \\
\hline 11 & 10348000 & Truckee River at Reno, Nev. & 59.07 & $\begin{array}{l}39^{\circ} 31 ' 53^{\prime \prime} \mathrm{N} . \\
119^{\circ} 47^{\prime} 07^{\prime \prime} \mathrm{W}\end{array}$ & S & $\begin{array}{l}\text { Sampled at old gaging station located under US } \\
395 \text { bridge near left bank. }\end{array}$ \\
\hline 12 & 10350000 & Truckee River at Vista, Nev. & 53.38 & $\begin{array}{l}39^{\circ} 31^{\prime} 14^{\prime \prime} \mathrm{N} . \\
119^{\circ} 42^{\prime} 00^{\prime \prime} \mathrm{W}\end{array}$ & S & Sampled near right bank at gaging station. \\
\hline
\end{tabular}


a fluorescent substance when that substance is subjected to a light source of an appropriate wavelength. The higher the concentration of the fluorescent substance, the more emitted light the fluorometer detects. When the dye plume arrived at a given site, 8-28 samples were taken in the main flow of the river at time intervals adequate to define the time-concentration (response) curve. Samples were collected manually at single points in the river. Fluorometer measurements were made in the field at the time of sampling to guide the frequency and duration of sampling for each dye plume. After field measurement, samples were stored out of sunlight in 1-ounce glass bottles for later analysis under laboratory conditions.

Streamflow measurements were made at each sampling site. In those instances where direct streamflow measurements were not made while dye was present, streamflow-gaging station data from nearby stations were substituted or were used to estimate the flow within a reach during the period when dye was present. Also, flow data on agricultural and municipal diversions were obtained from the Federal Water Master (Dave Wathen, U.S. District Court, written commun., 2006) and hydroelectric ditch diversion data were obtained from Truckee Meadows Water Authority (Bill Haulk, Truckee Meadows Water Authority, oral commun., 2007).

The samples collected in the field were reanalyzed under more-controlled laboratory conditions because sample temperatures experienced in the field varied and were different from those used to calibrate the fluorometer. Aside from dye concentration, sample temperature is the most significant factor affecting the fluorescence of a dilute solution. The fluorometer was calibrated in the lab according to procedures described by Wilson and others (1986) using standard solutions prepared from the same dye lot that was used in the field. The raw data shown in tables and figures in this report are the dye concentrations that were measured in the laboratory.

\section{Quality Assurance}

Quality-assurance procedures used in this study involved comparing field and laboratory measurements of dye concentrations. In general, dye concentrations recorded in the laboratory differed slightly from those measured in the field; however, the trend in concentration was consistent between field and laboratory values.

Plotted dye concentrations were compared to expected patterns and within a given reach. The dye curves were similar to those presented by Kilpatrick and Wilson $(1989$, p. 3), in that the peak concentration was reduced and the dye plume increased in length as it moved downstream.

\section{Dye-Tracing Results}

Data collected during the 2006 and 2007 dye injections are presented in tables 2-4 and are plotted in figures 2-4. The tabulated data include injection site, time, and volume; distance downstream from injection; and streamflows during sampling period, sampling times, and dye concentrations.

Data for the Truckee River reach from Tahoe City, Calif., (site 1) to Boca Bridge near Truckee, Calif., (site 6) was collected under medium-flow conditions (table 2). Data for the reach from Glenshire Drive near Truckee, Calif., (site 5) to Mogul, Nev., (site 9) was collected under high-flow conditions (table 3). Data for the reach from Mogul, Nev., (site 9) to Vista, Nev., (site 12) was collected under high-flow conditions (table 4).

During medium-flow conditions, flows ranged from 143 to $637 \mathrm{ft}^{3} / \mathrm{s}$. A discharge measurement could not be made at Boca Bridge near Truckee (site 6, table 2); streamflow was determined from the recorded gage data at that site. Data for the Truckee River below Squaw Creek (site 2; table 2 and fig. 2 ) indicates that adequate mixing had not yet occurred at this location and that the samples tend to be biased to that part of the river with dye.

During high-flow conditions, flows ranged from 1,260 to $2,660 \mathrm{ft}^{3} / \mathrm{s}$ (tables 3 and 4). At those sites near USGS gaging stations, the streamflow was determined from the recorded gage data. For the sites at Verdi (site 8) and West McCarran (site 10), discharges were estimated on the basis of discharge data from nearby USGS streamflow-gaging stations. For the site at Vista (site 12, table 4), the dye was moving faster than predicted and the field crew did not arrive on-site until after the dye peak had passed.

Variations in discharge between sites are mostly the result of diversions and tributaries between sites. The reduction in discharge between the sites at Farad and at Verdi (sites 7 and 8 , table 3 ) is due in large part to a diversion for hydropower, which returns the water to the river above the site near Mogul (site 9, table 3).

Dye concentrations were estimated using graphical analyses of the raw data according to the methods described by Kilpatrick and Wilson (1989) when either the first sample at a site was collected after first arrival of the dye or the last sample was collected before the dye concentrations reached $0.2 \mu \mathrm{g} / \mathrm{L}$. This method was not used to determine the estimated arrival of the dye at Vista (site 12), since no samples were obtained on the rising limb of the response curve.

As the dye travels downstream, the peak concentration is lower and the elapsed time for passage of the dye plume is longer (figs. 2-4). For example, during high-flow conditions on the reach between Glenshire Drive near Truckee, Calif. and Mogul, Nev. (table 3), the peak concentration was $18 \mu \mathrm{g} / \mathrm{L}$ at Boca Bridge (site 6); $8.6 \mu \mathrm{g} / \mathrm{L}$ at Farad (site 7); $5.8 \mu \mathrm{g} / \mathrm{L}$ at Verdi (site 8); and $4.7 \mu \mathrm{g} / \mathrm{L}$ at Mogul (site 9). The amount of time that the dye concentration was greater than 10 percent of the peak concentration was about 25 minutes at Boca Bridge (site 6), about 1 hour at Farad (site 7), about 1 hour and 30 minutes at Verdi (site 8), and about 1 hour and 45 minutes at Mogul (site 9). All reaches showed similar patterns. Because the dye plume moved more slowly during medium-flow conditions than during high-flow conditions, it took longer for the dye to pass each site. 


\section{Summary}

In 2006 and 2007, dye was injected into the Truckee River between Tahoe City, Calif., and Vista, Nev., on three occasions under high- and moderate-flow conditions. Two injections were during high-flow conditions (greater than $1,000 \mathrm{ft}^{3} / \mathrm{s}$ ) and one injection was during medium-flow conditions (143-637 ft $3 / \mathrm{s})$. The three Truckee River reaches studied were from Tahoe City, Calif., to Boca Bridge near Truckee, Calif.; from Glenshire Drive near Truckee, Calif., to Mogul, Nev.; and from Mogul, Nev., to Vista, Nev.

The results document the traveltime characteristics of the dye plume at sampling sites within each study reach. As the dye moved downstream, the peak concentration was lower and the elapsed time for passage of the dye plume was longer. During medium-flow conditions, the dye took longer to pass each site and traveled more slowly than during high-flow conditions.

\section{References}

Bohman, L.R., 2000, Estimation of traveltime characteristics for Truckee River between Truckee, California, and Marble Bluff Dam near Nixon, Nevada, and for Truckee Canal in Nevada: U.S. Geological Survey Water-Resources Investigations Report 99-4226, 53 p.

Brown, W.M., III, Nowlin, J.O., Smith, L.H., and Flint, M.R., 1986, River-quality assessment of the Truckee and Carson River systems, California and Nevada-Hydrologic characteristics: U.S. Geological Survey Open-File Report 84-576, $201 \mathrm{p}$.

Buchanan, T.J., 1964, Time of travel of soluble contaminants in streams: American Society of Civil Engineers Proceedings, Journal of the Hydraulics Division, v. 90, no. SA3, p. 1-12.

Caupp, C.L., Brock, J.T., and Runke, H.M., 1997, Application of the dynamic stream simulation and assessment model (DSSAMt) to the Truckee River below Reno, NevadaModel formulation and overview: Boise, Idaho, Rapid Creek Research Technical Report No. RCR96-1.1, 107 p.
Crompton, E.J., and Bohman, L.R., 2000, Traveltime data for Truckee River between Tahoe City, California, and Marble Bluff Dam near Nixon, Nevada; U.S. Geological Survey Open-File Report 00-363, 24 p.

Jones, Jeanine, Maxwell, S.R., and Hayward, Patricia, 1991, Truckee River atlas: California Department of Water Resources, 128 p.

Kilpatrick, F.A., and Wilson, J.F., Jr., 1989, Measurement of time of travel in streams by dye tracing: U.S. Geological Survey Techniques of Water-Resources Investigations, book 3, chap. A9, 27 p.

La Camera, R.J., Hoffman, R.J., Nowlin, J.O., Smith, L.H., and Lima, S.M., 1985, Data on surface-water quality and quantity, Truckee River system, Nevada and California, 1979-81: U.S. Geological Survey Open-File Report 84-238, 191 p.

Nowlin, J.O., 1987, Modeling nutrient and dissolved-oxygen transport in the Truckee River and Truckee Canal downstream from Reno, Nevada: U.S. Geological Survey WaterResources Investigations Report 87-4037, 487 p.

Nowlin, J.O., Brown, W.M., III, Smith, L.H., and Hoffman, R.J., 1980, Planning and design of studies for river-quality assessment in the Truckee and Carson River Basins, California and Nevada: U.S. Geological Survey Open-File Report $80-435,75$ p.

Van Denburgh, A.S., Lamke, R.D., and Hughes, J.L., 1973, A brief water-resources appraisal of the Truckee River Basin, western Nevada: Nevada Division of Water Resources Reconnaissance Report 57, 122 p.

Wilson, J.F., Jr., 1968, Time-of-travel measurements and other applications of dye tracing, in International Union of Geodesy and Geophysics Commission of Surface Waters, Hydrological aspects of the utilization of water: International Association of Scientific Hydrology Publication 76, p. 252-265.

Wilson, J.F., Jr., Cobb, E.D., and Kilpatrick, F.A., 1986, Fluorometric procedures for dye tracing: U.S. Geological Survey Techniques of Water-Resources Investigations, bk. 3, chap. A12, 41 p. 
Table 2. Rhodamine WT dye concentration data from traveltime study on the Truckee River between Tahoe City, Calif., and Boca Bridge near Truckee, Calif., May 22-24, 2007

Injection site: Truckee River at Tahoe City, Calif. (site 1)

Date and time of injection: May 22, 2007 at 2230

Streamflow, in cubic feet per second: 66

Volume of injected dye, in liters: 3.3

Injected dye mass, in kilograms: 0.82

[Dye concentration in micrograms per liter]

\begin{tabular}{|c|c|c|c|c|c|c|c|c|c|c|}
\hline & \multicolumn{2}{|c|}{$\begin{array}{c}\text { Truckee River below } \\
\text { Squaw Creek near } \\
\text { Tahoe City, Calif. }\end{array}$} & \multicolumn{2}{|c|}{$\begin{array}{l}\text { Truckee River near } \\
\text { Truckee, Calif. }\end{array}$} & \multicolumn{2}{|c|}{$\begin{array}{l}\text { Truckee River at } \\
\text { Brockway Road at } \\
\text { Truckee, Calif. }\end{array}$} & \multicolumn{2}{|c|}{$\begin{array}{c}\text { Truckee River at } \\
\text { Glenshire Drive near } \\
\text { Truckee, Calif. }\end{array}$} & \multicolumn{2}{|c|}{$\begin{array}{l}\text { Truckee River at } \\
\text { Boca Bridge near } \\
\text { Truckee, Calif. }\end{array}$} \\
\hline Site Number & & 2 & & 3 & & 4 & & 5 & & 6 \\
\hline $\begin{array}{l}\text { Distance downstream from } \\
\text { injection site, in river miles }\end{array}$ & & 6.15 & & 12.63 & & 15.39 & & 20.08 & & 25.01 \\
\hline \multirow{33}{*}{$\begin{array}{l}\text { Streamflow during sampling } \\
\text { period, in cubic feet per second }\end{array}$} & \multicolumn{2}{|r|}{143} & \multicolumn{2}{|r|}{194} & \multicolumn{2}{|r|}{266} & \multicolumn{2}{|r|}{267} & \multicolumn{2}{|r|}{637} \\
\hline & \multicolumn{2}{|r|}{ May 23} & \multicolumn{2}{|r|}{ May 23} & \multicolumn{2}{|r|}{ May 23} & \multicolumn{2}{|c|}{ May 23-24 } & \multicolumn{2}{|r|}{ May 23-24 } \\
\hline & Time & Concentration & Time & Concentration & Time & Concentration & Time & Concentration & Time & Concentration \\
\hline & 0532 & 0.0 & 1205 & ${ }^{1} 0.2$ & 1355 & ${ }^{1} 0.2$ & 1655 & 0.0 & 2140 & 0.2 \\
\hline & 0658 & ${ }^{1} .2$ & 1215 & .5 & 1400 & 1.0 & 1710 & .05 & 2200 & .4 \\
\hline & 0710 & .6 & 1230 & 1.2 & 1430 & 0.6 & 1725 & .1 & 2220 & .6 \\
\hline & 0720 & 1.1 & 1245 & 2.3 & 1448 & 1.4 & 1740 & .2 & 2240 & 1.0 \\
\hline & 0730 & 2.6 & 1300 & 3.8 & 1500 & 2.1 & 1755 & .4 & 2300 & 1.4 \\
\hline & 0740 & 3.6 & 1315 & 6.0 & 1515 & 2.8 & 1810 & .7 & 2320 & 1.8 \\
\hline & 0750 & 5.6 & 1330 & 7.6 & 1530 & 3.4 & 1825 & 1.2 & 2340 & 2.2 \\
\hline & 0800 & 6.6 & 1345 & 9.4 & 1545 & 5.6 & 1840 & 1.8 & 2400 & 2.0 \\
\hline & 0810 & 10.5 & 1400 & 10.0 & 1600 & 6.4 & 1855 & 3.0 & 0020 & 2.6 \\
\hline & 0820 & 13.0 & 1415 & 11.2 & 1615 & 7.0 & 1910 & 3.8 & 0040 & 2.0 \\
\hline & 0830 & 15.0 & 1430 & 11.2 & 1630 & 8.1 & 1925 & 5.0 & 0100 & 2.0 \\
\hline & 0840 & 13.5 & 1445 & 11.5 & 1645 & 8.0 & 1940 & 5.2 & 0120 & 1.7 \\
\hline & 0850 & 16.5 & 1500 & 10.8 & 1700 & 7.6 & 1955 & 5.8 & 0140 & 1.6 \\
\hline & 0900 & 18.8 & 1515 & 11.0 & 1715 & 7.2 & 2010 & 6.2 & 0200 & 1.3 \\
\hline & 0910 & 25.1 & 1530 & 9.0 & 1730 & 6.8 & 2025 & 6.4 & 0230 & 1.2 \\
\hline & 0920 & 24.0 & 1600 & 7.6 & 1745 & 6.4 & 2040 & 6.2 & 0300 & .8 \\
\hline & 0930 & 22.8 & 1630 & 5.8 & 1800 & 6.0 & 2105 & 5.8 & 0330 & .6 \\
\hline & 0940 & 16.1 & 1700 & 4.2 & 1815 & 4.0 & 2125 & 5.2 & 0400 & .5 \\
\hline & 0950 & 14.9 & 1730 & 2.7 & 1830 & 4.4 & 2150 & 4.2 & 0530 & ${ }^{1} .2$ \\
\hline & 1000 & 12.2 & 1800 & 2.3 & 1845 & 4.4 & 2215 & 3.6 & & \\
\hline & 1015 & 14.0 & 1830 & 1.7 & 1900 & 3.6 & 2240 & 3.2 & & \\
\hline & 1030 & 11.0 & 1950 & ${ }^{1} .2$ & 1915 & 3.0 & 2305 & 2.3 & & \\
\hline & 1045 & 11.8 & & & 1930 & 2.6 & 2335 & 1.8 & & \\
\hline & 1100 & 8.1 & & & 1945 & 2.3 & 2400 & 1.4 & & \\
\hline & 1115 & 7.9 & & & 2000 & 1.9 & 0025 & 1.0 & & \\
\hline & 1130 & 8.6 & & & 2015 & 1.6 & 0055 & .8 & & \\
\hline & 1145 & 7.2 & & & 2030 & 1.3 & 0210 & ${ }^{1} .2$ & & \\
\hline & 1200 & 6.2 & & & 2130 & ${ }^{1} .2$ & & & & \\
\hline & 1215 & 5.5 & & & & & & & & \\
\hline & 1400 & ${ }^{1} .2$ & & & & & & & & \\
\hline
\end{tabular}

${ }^{1}$ Estimated. 


\section{Traveltime Data for the Truckee River Between Tahoe City, California, and Vista, Nevada, 2006 and 2007}

Table 3. Rhodamine WT dye concentration data from traveltime study on the Truckee River between Glenshire Drive near Truckee, Calif., and Mogul, Nev., June 29, 2006.

Injection site: Truckee River at Glenshire Drive near Truckee, Calif. (site 5)

Date and time of injection: June 29, 2006 at 0605

Streamflow, in cubic feet per second: 12,130

Volume of injected dye, in liters: 5.2

Injected dye mass, in kilograms: 1.30

[Dye concentration in micrograms per liter]

\begin{tabular}{|c|c|c|c|c|c|c|c|c|}
\hline & \multicolumn{2}{|c|}{$\begin{array}{c}\text { Truckee River at Boca } \\
\text { Bridge near Truckee, } \\
\text { Calif. }\end{array}$} & \multicolumn{2}{|c|}{$\begin{array}{l}\text { Truckee River at river } \\
\text { put-in at Farad, Calif. }\end{array}$} & \multicolumn{2}{|c|}{$\begin{array}{l}\text { Truckee River at Bridge } \\
\text { Street at Verdi, Nev. }\end{array}$} & \multicolumn{2}{|c|}{$\begin{array}{c}\text { Truckee River } \\
\text { near Mogul, Nev. }\end{array}$} \\
\hline Site number & \multicolumn{2}{|r|}{6} & \multicolumn{2}{|r|}{7} & \multicolumn{2}{|r|}{8} & \multicolumn{2}{|r|}{9} \\
\hline $\begin{array}{l}\text { Distance downstream from } \\
\text { injection site, in river miles }\end{array}$ & \multicolumn{2}{|r|}{4.85} & \multicolumn{2}{|r|}{13.68} & \multicolumn{2}{|r|}{22.59} & \multicolumn{2}{|c|}{27.35} \\
\hline \multirow{19}{*}{$\begin{array}{l}\text { Streamflow during sampling } \\
\text { period, in cubic feet per second }\end{array}$} & \multicolumn{2}{|c|}{2,260} & \multicolumn{2}{|c|}{2,660} & \multicolumn{2}{|c|}{${ }^{12} 2,010$} & \multicolumn{2}{|c|}{2,180} \\
\hline & Time & Concentration & Time & Concentration & Time & Concentration & Time & Concentration \\
\hline & 0715 & 0.0 & 0830 & 0.02 & 1035 & 0.02 & 1340 & 0.0 \\
\hline & 0719 & .8 & 0850 & .04 & 1051 & .02 & 1355 & .3 \\
\hline & 0721 & 2.8 & 0920 & .02 & 1202 & .12 & 1405 & .9 \\
\hline & 0723 & 8.0 & 0940 & .24 & 1217 & 1.4 & 1415 & 2.1 \\
\hline & 0733 & 17 & 095730 & 5.6 & 1311 & 2.8 & 1503 & 3.1 \\
\hline & 0735 & 15 & 1000 & 6.8 & 1322 & 1.6 & 1518 & 1.8 \\
\hline & 0738 & 11 & 100230 & 7.4 & 1334 & .64 & 1537 & .6 \\
\hline & 0741 & 8.8 & 1005 & 8.2 & 1343 & .44 & 1554 & .2 \\
\hline & 0744 & 5.4 & 100730 & 8.4 & 1353 & .26 & 1609 & .24 \\
\hline & 0748 & 3.0 & 1010 & 8.6 & 1403 & .20 & 1624 & .16 \\
\hline & 0752 & 1.6 & 101230 & 8.2 & 1415 & .12 & 1638 & .12 \\
\hline & 0756 & .82 & 1015 & 7.6 & 1428 & .16 & 1653 & .10 \\
\hline & 0800 & .50 & 101730 & 7.0 & 1438 & .10 & & \\
\hline & 0805 & .28 & 1020 & 5.8 & 1449 & .10 & & \\
\hline & & & 1100 & .32 & & & & \\
\hline & & & 1110 & .20 & & & & \\
\hline & & & 1120 & .22 & & & & \\
\hline
\end{tabular}

${ }^{1}$ Estimated. 
Table 4. Rhodamine WT dye concentration data from traveltime study on the Truckee River between Mogul, Nev., and Vista, Nev., June 27, 2006

Injection site: Truckee River near Mogul, Nev. (site 9)

Date and time of injection: June 27, 2006 at 0701

Streamflow, in cubic feet per second: 1,390

Volume of injected dye, in liters: 1.85

Injected dye mass, in kilograms: 0.46

[Dye concentration in micrograms per liter]

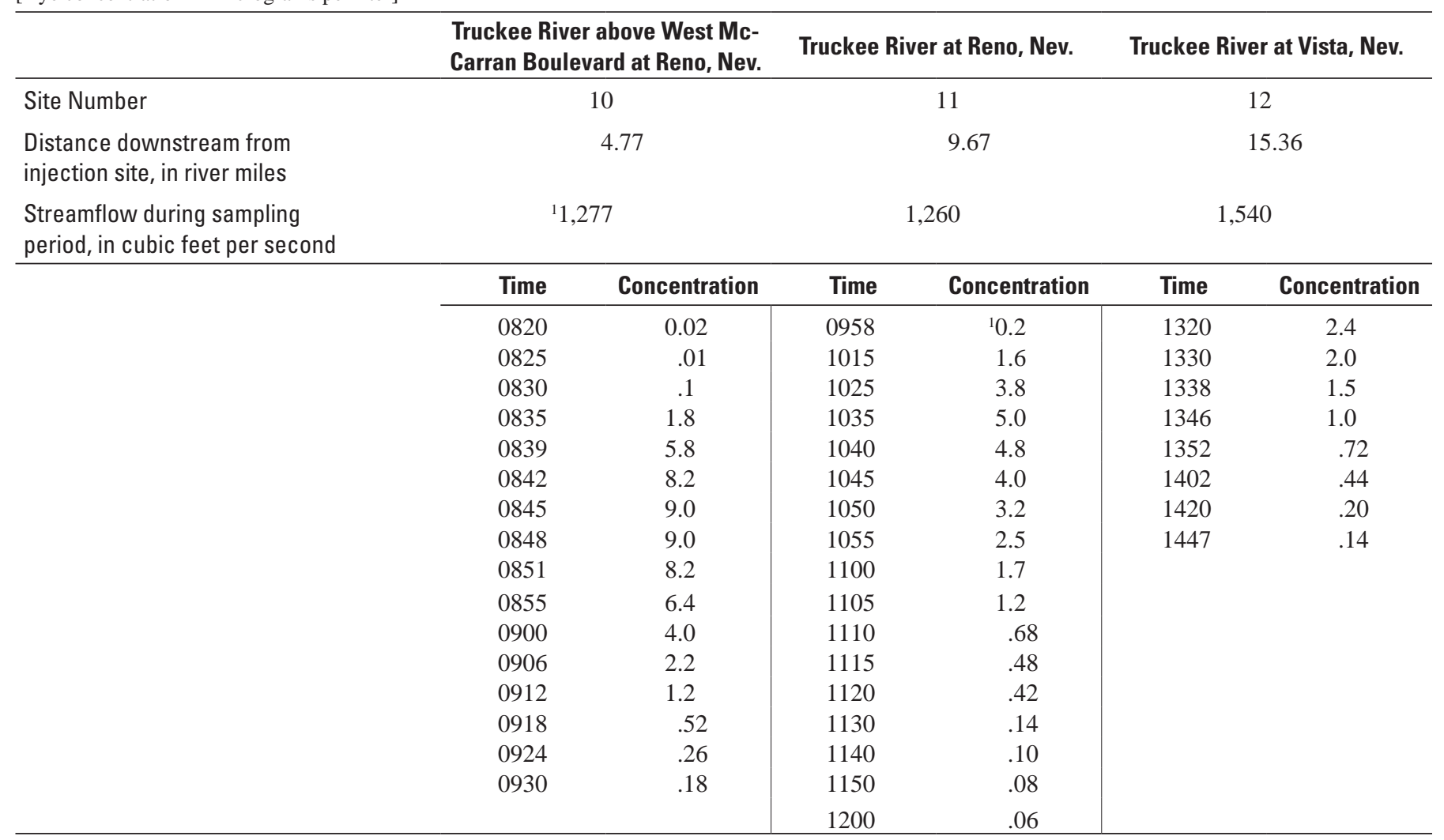

${ }^{1}$ Estimated. 


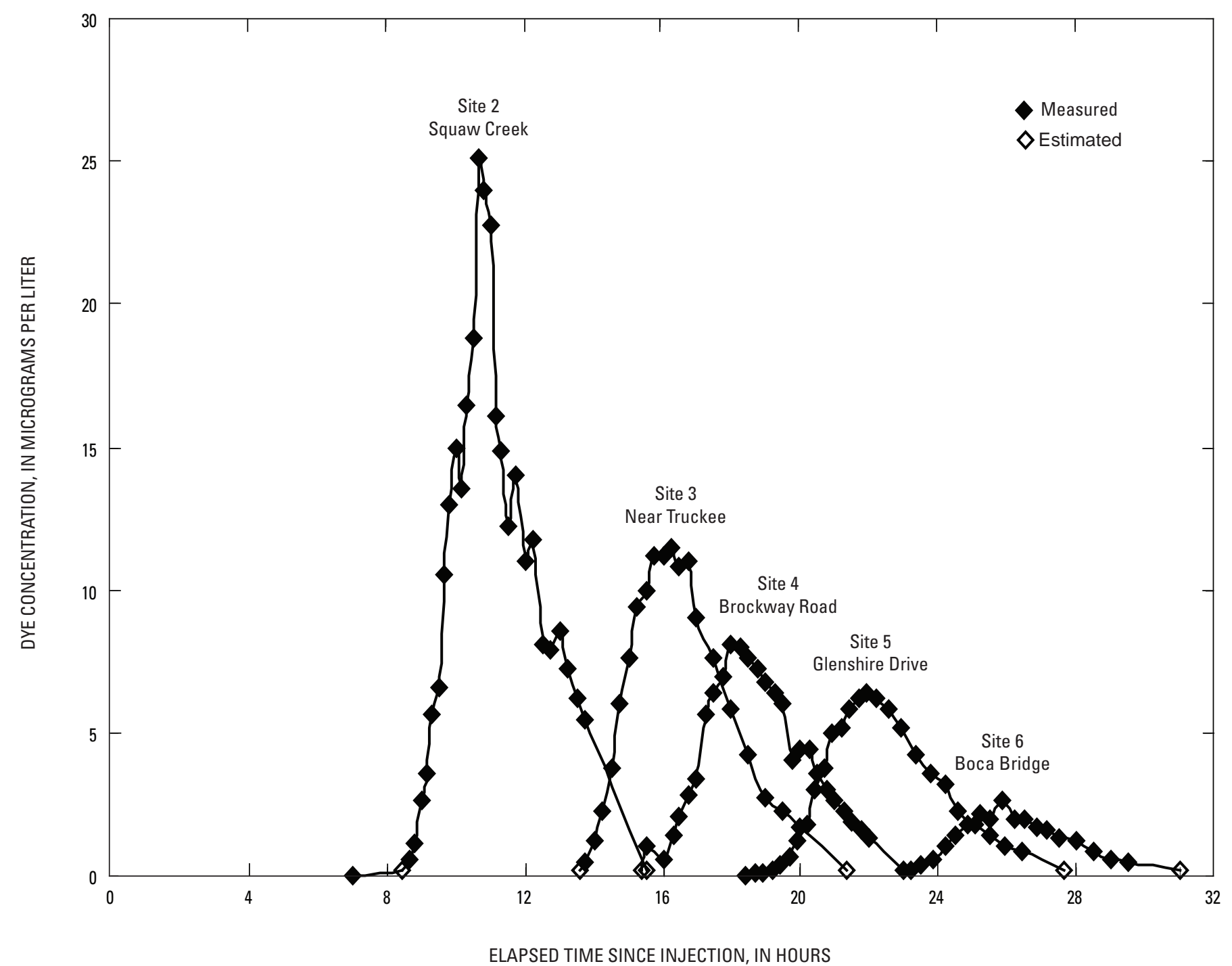

Figure 2. Observed response curves for the Truckee River reach between Tahoe City, Calif., and Boca Bridge near Truckee, Calif., May 22-24, 2007. See table 1 for full site names. 


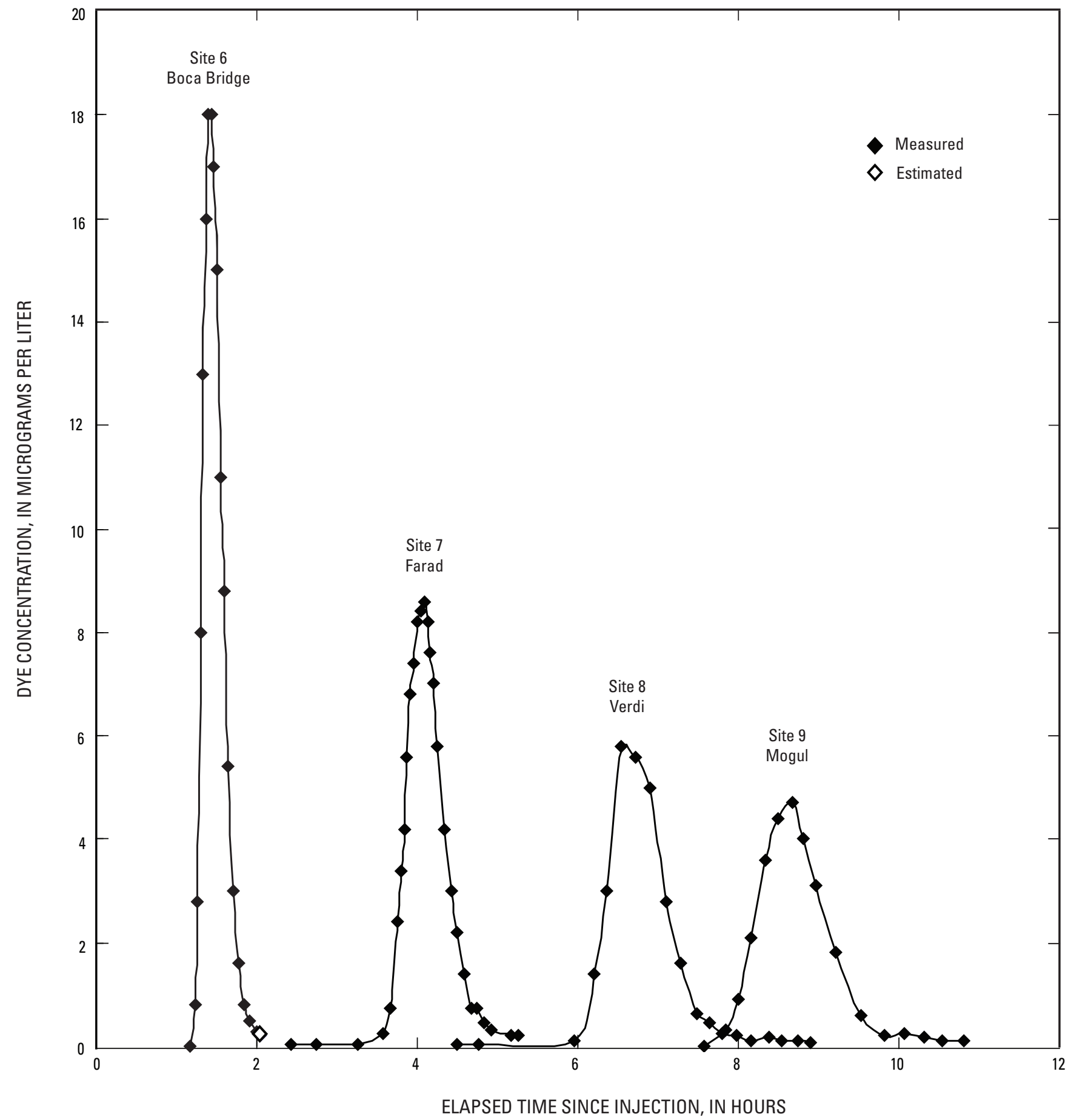

Figure 3. Observed response curves for the Truckee River reach between Glenshire Drive near Truckee, Calif., and Mogul, Nev., June 29,2006 . See table 1 for full site names. 
Traveltime Data for the Truckee River Between Tahoe City, California, and Vista, Nevada, 2006 and 2007

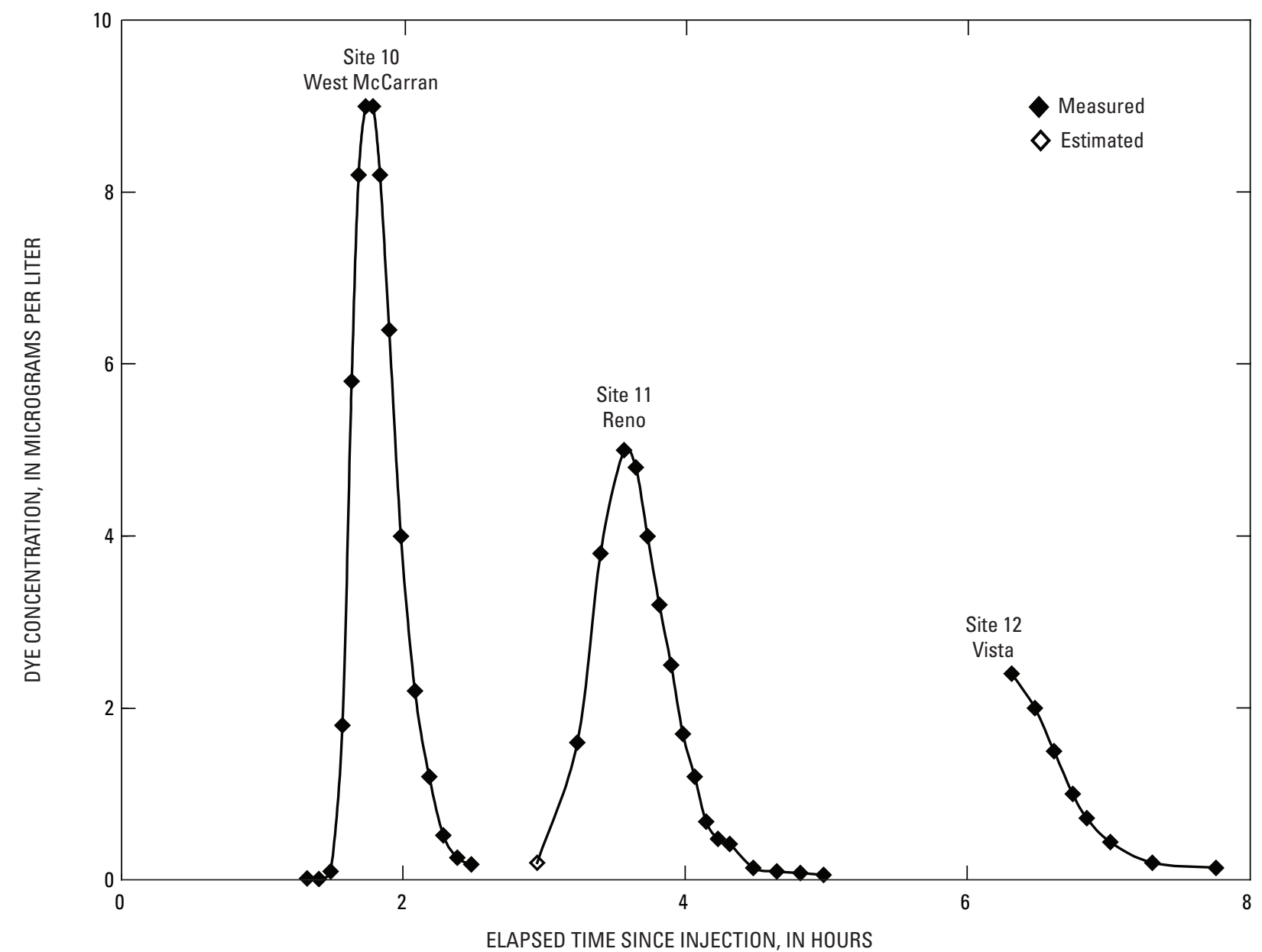

Figure 4. Observed response curves for the Truckee River reach between Mogul, Nev., and Vista, Nev., June 27, 2006. See table 1 for full site names. 
Printed on recycled paper 